\title{
Biofilm Bakteri pada Penderita Rinosinusitis Kronis
}

\section{Bacterial Biofilm in Chronic Rhinosinusitis Patients}

\author{
Yolazeniia ${ }^{1,2 *}$, Bestari Jaka Budiman², Dolly Irfandy ${ }^{2}$ \\ ${ }^{1}$ KJF Parasitologi Fakultas Kedokteran Universitas Riau, ${ }^{2}$ Bagian Ilmu Penyakit THT-KL Fakultas Kedokteran Universitas Andalas,
}

\begin{abstract}
ABSTRAK
Banyak dilaporkan kegagalan pengobatan pada rinosinusitis kronis (RSK) disebabkan resistensi terhadap antibiotik. Beberapa penelitian menunjukkan bahwa biofilm bakteri berperan penting pada etiologi dan persistensi dari RSK. Penulisan tinjauan pustaka ini adalah untuk mengetahui implikasi biofilm bakteri pada penderita RSK. Rinosinusitis kronis adalah penyakit inflamasi mukosa hidung dan sinus paranasal yang berlangsung dalam waktu lebih dari 12 minggu. Biofilm adalah suatu struktur komunitas sel-sel bakteri yang ditutupi oleh matriks polimer yang dihasilkan sendiri dan menempel pada permukaan. Berbagai penelitian menunjukkan terdapatnya biofilm bakteri pada mukosa sinonasal penderita RSK dan berhubungan dengan resistensi terhadap pengobatan dengan antibiotika. Berbagai pemeriksaan untuk mendeteksi biofilm yaitu Scanning Electron Microscopy (SEM), Transmission Electron Microscopy (TEM), Confocal Scanning Laser Microscopy (CSLM), modifikasi Calgary Biofilm Device Assay, Tube Method dan Congo Red Agar Method. Beberapa terapi potensial untuk mengatasi biofilm pada RSK sedang berkembang.
\end{abstract}

Kata kunci: biofilm, Calgary Biofilm Device Assay, rinosinusitis kronis, Scanning Electron Microscopy (SEM), tube method

\begin{abstract}
It has been reported the failure of treatment chronic rhinosinusitis (CRS) due to antibiotic resistance. There is mounting evidence that bacterial biofilms play an important role in the etiology and persistence of CRS. The purpose of this literature review is to know the implications of bacterial biofilms in chronic rhinosinusitis patients. Chronic rhinosinusitis is an inflammation of the nose and paranasal sinuses within more than 12 weeks. Biofilm is defined as a structured community of bacterial cells enclosed in a self-produced polymeric matrix and adherent to an inert or living surface. Several studies showed evidence of bacterial biofilm on the sinonasal mucosal CRS patients and contributing to antibiotic resistance. Various methods to detect biofilm are Scanning Electron Microscopy (SEM), Transmission Electron Microscopy (TEM), Confocal Scanning Laser Microscopy (CSLM), modified Calgary Biofilm Device Assay, Tube Method and Congo Red Agar Method. Potential biofilm treatments in CRS have been conducted.
\end{abstract}

Key words: biofilm, Calgary Biofilm Device Assay, chronic rhinosinusitis, Scanning Electron Microscopy (SEM), tube method

*Korespondensi: Yolazenia, email: yolazenia@lecturer.unri.ac.id

Artikel info: Online published first 25 April 2018; Received 12 Januari 2018; Accepted 5 Maret 2018.

DOI: https://doi.org/10.26891/jkm.v1i2.2018.106-113

Copyright @ 2018 Yolazenia, Bestari Jaka Budiman, dan Dolly Irfandy. This is an open access article distributed under the terms of the Creative Commons Attribution-NonCommercial 4.0 International License (http://creativecommons.org/licenses/by-nc/4.0/), which permits unrestricted non-commercial use, distribution, and reproduction in any medium, provided the original author and source are properly cited. 
Rinosinusitis kronis (RSK) adalah penyakit inflamasi mukosa hidung dan sinus paranasal yang prevalensinya cukup tinggi dan sering pengobatan belum bisa optimal disebabkan banyaknya faktor penyebab seperti gen, lingkungan, infeksi dan akhirakhir ini banyak dibicarakan resistensi kuman berhubungan dengan superantigen dan biofilm. Rinosinusitis kronis tidak hanya mempengaruhi kualitas hidup pasien tetapi juga menyebabkan tingginya biaya kesehatan disebabkan tingginya angka kegagalan pengobatan. Di Amerika Serikat, lebih dari 13 juta kunjungan dokter/tahun dan menghabiskan dana kesehatan sekitar 6 milyar dolar/tahun untuk penderita RSK. ${ }^{2}$ Prevalensi RSK di Amerika Serikat per tahun sekitar $13-16 \%{ }^{1}$

Patofisiologi dari RSK masih belum terjelaskan secara pasti. Berbagai kondisi telah dikaitkan dengan patogenesis penyakit ini, seperti infeksi bakteri gram positif dan gram negatif, jamur dan superantigen. Akhir-akhir ini, banyak penelitian berhubungan dengan kemungkinan peran dari biofilm bakteri pada RSK yang tidak dapat diobati. ${ }^{2}$

Biofilm adalah suatu struktur komunitas sel-sel bakteri yang ditutupi oleh matriks polimer yang dihasilkan sendiri dan menempel pada permukaan. ${ }^{3}$ Biofilm telah dikenal berperan penting dalam patogenesis berbagai infeksi pada manusia. Centers for Disease Control and Prevention (CDC) di Amerika Serikat memperkirakan sedikitnya $65 \%$ dari semua bakteri yang infeksius pada manusia melibatkan biofilm, dan hal ini berhubungan dengan kronisitas infeksi. ${ }^{4-6}$ Biofilm terbukti berperan pada berbagai infeksi kronis di bidang telinga-hidung-tenggorok (THT) seperti otitis media kronis, ${ }^{7}$ tonsiloadenoiditis kronis, ${ }^{8}$ dan rinosinusitis kronis. ${ }^{2-6}$

Berbagai penelitian telah menunjukkan terdapatnya biofilm pada pasien dengan RSK. Prince et $\mathrm{al}^{2}$ mendapatkan 28,6\% dari pasien RSK dengan sekret mukopurulen mengandung biofilm. Sanclement et al, ${ }^{4}$ mendapatkan 24 (80\%) dari 30 pasien terdapat bukti adanya biofilm. Mekanisme pasti bagaimana peran biofilm pada patogenesis RSK masih belum jelas. $^{1}$

\section{METODE}

Penulisan artikel ini berdasarkan studi kepustakaan, yang membahas tentang etiopatogenesis RSK, Biofilm pada RSK terutama tentang definisi, metode pemeriksaan, terapi dan resistensi antibiotik.

\section{HASIL DAN PEMBAHASAN}

\section{Etiopatogenesis Rinosinusitis Kronis}

Rinosinusitis kronis dapat disebabkan oleh interaksi berbagai penyebab, termasuk faktor genetik, faktor lingkungan, faktor struktural dan faktor mikroba. ${ }^{1,9,10}$

\section{Faktor genetik}

Meningkatnya prevalensi RSK pada pasien dengan penyakit bawaan tertentu seperti fibrosis kistik telah mengarahkan penelitian pada kemungkinan mutasi gen sebagai presidisposisi RSK. Fibrosis kistik adalah suatu kelainan dimana terdapatnya defek genetik pada saluran transport klorida yang mengacu pada disfungsi eksokrin multisistem, paling terlihat pada sistem pencernaan dan pernafasan. Penyakit ini juga menyebabkan pengaruh yang signifikan pada sinonasal menyebabkan edema mukosa, sinusitis kronis, dan polip nasi. Lebih dari $90 \%$ pasien fibrosis kistik menunjukkan bukti kelainan pada sinus secara radiologi, dan penelitian telah menunjukkan bahwa keterlibatan sinonasal menyebabkan morbiditas yang berarti pada pasien ini. ${ }^{1}$

Pada penelitian tahun 2000 didapatkan bahwa mutasi gen pada fibrosis kistik secara signifikan lebih banyak pada pasien RSK dibandingkan kontrol. Penelitian genom untuk menilai kerentanan RSK mengidentifikasi polimorfisme pada gen TNF- $\alpha$, MMP-9, IL-13, IL-33 dan IL1A telah dihubungkan dengan peningkatan kerentanan terhadap RSK. ${ }^{1,9}$

\section{Faktor lingkungan}

Perokok aktif maupun pasif telah terbukti berperan sebagai faktor penyerta terhadap terjadinya RSK. ${ }^{1,10,11}$ Cohen et al, $^{12}$ menunjukkan terjadinya penurunan frekuensi gerakan siliar dan kerusakan sekresi klorida transepitelial pada sel epitel sinonasal manusia sewaktu dipaparkan dengan kondensat asap rokok. ${ }^{12}$

Polutan lingkungan lain juga dapat berefek pada saluran pernafasan atas sebagai predisposisi untuk RSK. Penelitian pada pekerja kebersihan di gedung World Trade Center yang kena bencana, menunjukkan hubungan yang jelas antara paparan polusi lingkungan dan penyakit pada saluran pernafasan atas, terutama pada pasien dengan riwayat atopi. ${ }^{13}$

\section{Faktor struktural}

Kompleks ostiomeatal (KOM) merupakan tempat drainase bagi kelompok sinus anterior (frontalis, ethmoid anterior dan maksilaris) dan berperan penting bagi transport mukus dan debris serta 
mempertahankan tekanan oksigen yang cukup untuk mencegah pertumbuhan bakteri. Obstruksi ostium sinus pada KOM merupakan faktor predisposisi yang berperan penting untuk terjadinya RSK. Obstruksi ostium sinus KOM akan mengakibatkan akumulasi dan hambatan cairan, membentuk lingkungan yang lembab dan suasana hipoksia yang ideal bagi pertumbuhan kuman patogen. Obstruksi KOM dapat disebabkan oleh berbagai kelainan anatomis seperti deviasi septum, konka bulosa, konka media paradoks, sel Haller, jaringan parut akibat bekas operasi dan anomali kraniofasial. Pada anak, benda asing harus selalu dipikirkan sebagai kemungkinan lain penyebab sumbatan KOM pada sinusitis. ${ }^{1,9}$

\section{Faktor mikroba}

Peran pasti bakteri pada RSK telah menjadi topik yang kontroversi pada dekade terakhir ini. Hasil kultur bakteri dari sinus pasien dengan RSK juga ditemukan pada orang normal. Dengan diidentifikasinya superantigen dan biofilm bakteri berhubungan dengan RSK, menunjukkan bahwa bakteri memiliki peran yang jauh lebih komplek terhadap etiologi RSK. ${ }^{1}$

Spesies bakteri yang paling umum ditemukan pada pasien dengan RSK adalah Staphylococcus aureus, Pseudomonas aeroginosa, Staphylococcus koagulase negatif, S. pneumoniae, dan Moraxella catarrhalis. ${ }^{14}$ Boase et al, ${ }^{15}$ menemukan $79 \%$ pasien RSK dengan lebih dari 1 spesies bakteri. S. aureus merupakan organisme yang paling sering ditemukan diikuti $S$. epidermidis dan Propionibacterium acnes. ${ }^{15}$ Sedangkan bakteri yang paling umum ditemukan pada rinosinusitis akut adalah Streptococcus pneumoniae, Haemophilus influenzae, Staphylococcus aureus, dan Moraxella catarrhalis. ${ }^{1}$

Staphylococcus aureus telah diketahui memproduksi superantigen. Superantigen adalah eksotoksin yang dihasilkan mikroorganisme yang mempunyai kemampuan mengaktivasi jauh lebih banyak subpopulasi limfosit T dibandingkan antigen biasa. ${ }^{1}$

Foreman et al, ${ }^{16}$ dan Singhal et al, ${ }^{17}$ menemukan bahwa bakteri Staphylococcus aureus merupakan bakteri yang paling umum ditemukan membentuk biofilm pada pasien RSK. Biofilm merupakan bentuk yang disukai bakteri untuk eksistensinya, dan hanya sekitar $1 \%$ bakteri dalam bentuk bebas (free-floating planktonic form). ${ }^{1}$ Terdapatnya biofilm bakteri juga dihubungkan dengan inflamasi mukosa persisten setelah bedah sinus endoskopi. ${ }^{10}$

\section{Biofilm}

Definisi

Definisi biofilm berkembang secara konstan seiring dengan berkembangnya penelitian dan teknologi. Biofilm dapat didefinisikan sebagai suatu struktur komunitas sel-sel bakteri yang dibungkus oleh matriks polimer yang dihasilkan bakteri itu sendiri dan menempel pada permukaan. ${ }^{3}$ Sekarang terbukti bahwa biofilm bukan suatu struktur yang statis, homogen tapi lebih menunjukkan heterogenesitas sebagaimana banyak perbedaan pada angka pertumbuhan bakteri planktoniknya, metabolik dan ekspresi genetik. Biofilm dapat ditemukan pada semua bakteri hidup. Bakteri dalam biofilm berbeda secara genotip dan fenotip dari bentuk planktonik (bakteri yang terapung sebagai sel tunggal dalam air). Biofilm ini sangat sulit dikultur dan sangat resisten terhadap antibiotik konvensional. ${ }^{6,18}$

\section{Komposisi dan struktur}

Secara morfologi, biofilm berupa kompleks tiga dimensi dari bakteri yang ditutupi oleh matriks polimer ekstraseluler yang diproduksi oleh bakteri itu sendiri yang terdiri dari polisakarida, air, asam nukleat, protein dan DNA ekstraseluler. Sekitar $90 \%$ massa biofilm terdiri dari air dan $10 \%$ sisanya terdiri dari maktriks ekstraseluler (8,5\%) dan sel (1,5\%). ${ }^{6}$ Komposisi matriks kompleks dan bervariasi antar spesies bakteri berbeda dan bahkan antar spesies sama pada kondisi lingkungan berbeda.

Pada struktur biofilm terdapat pori-pori dan saluran air yang berfungsi untuk nutrisi dan pembuangan melalui pertukaran produk dengan lingkungan luar secara aktif dan pasif. Struktur fisik dari biofilm menunjukkan penurunan oksigen dan gradien nutrisi dari perifer ke tengah yang menyebabkan gradien metabolik bakteri pada arah sama, dengan kerentanan berbeda terhadap antibiotik dan imunitas. ${ }^{6}$

Kita biasanya berpendapat bahwa bakteri hidup pasti dapat dikultur dan berasumsi bahwa jika dari spesimen tidak tumbuh pada kultur membuktikan tidak terdapatnya kuman patogen. Bakteri yang tumbuh pada biofilm dapat dalam posisi "dorman" tapi viabel dan oleh karena itu dapat tidak tumbuh pada kultur. ${ }^{19}$

\section{Pembentukan biofilm}

Proses komunikasi antar sel yang menginisiasi pembentukan biofilm disebut dengan quorumsensing. Proses ini diinisiasi dengan produksi dan sekresi dari molekul sinyal yang dapat dipengaruhi 
oleh faktor lingkungan seperti status nutrisi, yang memicu jalur yang diperlukan untuk pembentukan biofilm. 6,18,19

Berdasarkan studi pada Pseudomonas aeruginosa disimpulkan terdapat 5 langkah dalam siklus hidup biofilm yaitu: langkah pertama (Reversible attachment) dimulai dengan kontak secara random dari biofilm dengan permukaan. Pada tahap ini belum terbentuk biofilm, jadi masih mudah lepas. Langkah kedua (irreversible attachment) adalah produksi maktriks ekstraseluler yang berfungsi sebagai adhesin yang melekatkan kompleks bakteri ke permukaan. Langkah ketiga (Aggregation) adalah pembentukan mikrokoloni. Pada tahap ini terjadi replikasi/agregrasi secara aktif dari organisme yang melekat pada permukaan sehingga terjadi peningkatan densitas dan kompleksitas dari keseluruhan biofilm. Pada langkah keempat (maturation) terjadi interaksi antar koloni bakteri dan substansi ekstraseluler yang dihasilkannya menghasilkan pematangan bentuk biofilm dan redistribusi organisme jauh dari substratum. Langkah kelima (detachment) terjadi saat biofilm mencapai massa kritis yang ditentukan oleh sejumlah kondisi lingkungan yang menginduksi pelepasan dari bakteri hidup bebas ke koloni yang lebih jauh untuk memelihara siklus bakteri. 6,18,20

Metoda pemeriksaan biofilm

1. Scanning electron microscopy (SEM) dan Transmission Electron Microscopy (TEM)

Kelebihan SEM adalah pada kemampuan untuk melihat gambar dengan magnifikasi tinggi, dengan detail struktur mikroskopik. Sedangkan kelebihan TEM adalah dapat menampilkan detail ultrastruktur biofilm, seperti komposisi dan interaksi maktriks ekstraselular dengan permukaan dan sel di sekitarnya. Kekurangan pemeriksaan dengan cara ini adalah terbentuknya artefak sewaktu memproses sampel, membutuhkan potongan yang sangat kecil untuk dianalisa sehingga bisa menambah kesalahan bias sampling. ${ }^{6}$ Pada metoda ini, setelah spesimen diambil (bisa menggunakan forsep biopsi pada mukosa sinus), lalu spesimen menjalani proses fiksasi dan dehidrasi sebelum diperiksa di bawah mikroskop SEM atau TEM. ${ }^{21}$

2. Confocal Scanning Laser Microscopy (CSLM)

Kelebihan CSLM adalah dapat memvisualisasi spesimen tanpa harus melalui proses fiksasi atau dehidrasi, sehingga meminimalisir kemungkinan perubahan bentuk biofilm, kemungkinan bisa mewarnai sel-sel bakteri atau jamur secara selektif dengan marker fluoresen, seperti probe yang digunakan untuk in situ hibridisasi (fluorescent in situ hybridization (FISH)) atau marker asam nukleat untuk membedakan sel viabel dari non viabel. ${ }^{6}$ Kekurangan metoda ini adalah diperlukan keahlian untuk spesifikasi bakteri yang dicari dan diperlukan biaya tambahan untuk identifikasi bakteri. ${ }^{2}$

\section{Modifikasi Calgary Biofilm Assay}

Modifikasi Calgary Biofilm Assay adalah uji in-vitro menggunakan plate 96 well untuk mengevaluasi kemampuan bakteri membentuk biofilm pada peg bundar yang terletak diatas plate. Metoda ini awalnya digunakan untuk mengevaluasi kerentanan/ resistensi biofilm terhadap antibiotik. ${ }^{22}$ Kelebihannya adalah mudah dan relatif murah. Kekurangannya adalah pembentukan biofilm yang dievaluasi pada peg belum tentu merefleksikan sifat yang sama invivo. $^{6}$

\section{Tube Method}

Tube method merupakan suatu pemeriksaan pembentukan biofilm secara kualitatif yang diperkenalkan oleh Christensen et al. ${ }^{23}$ Pemeriksaan ini menggunakan media Trypticase soy broth dengan glukosa $1 \%$ (TSBglu) pada tabung uji dan diinkubasi selama 24 jam pada suhu $37^{\circ} \mathrm{C}$. Tabung kemudian dicuci dengan Phosphat Buffer Saline (PBS) dan dikeringkan. Tabung kering ini lalu diwarnai dengan kristal violet $(0,1 \%)$. Sisa pewarnaan dibuang dan tabung dicuci dengan deionized water. Tabung kemudian dikeringkan dengan posisi terbalik dan dilihat adanya pembentukan biofilm. Pembentukan biofilm dikatakan positif jika terlihat lapisan berwarna keunguan menempel pada dinding dan dasar tabung. Pembentukan cincin hanya pada perbatasan cairan tidak mengindikasikan pembentukan biofilm. ${ }^{24,25}$

Tube method dapat digunakan sebagai pemeriksaan rutin pembentukan biofilm karena mudah, murah dan mempunyai sensitivitas dan spesifisitas yang cukup tinggi. $^{25}$ Pemeriksaan biofilm bakteri menggunakan tube method ini mempuyai sensitivitas $73 \%$ dan spesifisitas $92,5 \% .{ }^{26}$ Kekurangan metoda ini adalah sukar untuk membedakan isolat dengan biofilm lemah atau negatif disebabkan variabilitas penilaian antar pengamat yang berbeda sehingga dapat terjadi kesalahan subjektif. ${ }^{24}$

5. Congo Red Agar Method (CRA)

Metoda ini merupakan metoda alternatif untuk skrining pembentukan biofilm oleh isolat Staphylococcus yang digambarkan oleh Freeman et al. ${ }^{27}$ Media terdiri dari brain heart infusion broth (BHI), sukrosa, agar no.1 dan congo red stain. Hasil positif bila didapatkan koloni hitam dengan 
konsistensi kristalin kering, sedangkan bila ditemukan koloni berwarna kecoklatan atau kemerahan dianggap negatif. ${ }^{24,26}$ Menurut Hassan et al $^{26}$ metoda ini mempunyai sensitivitas $11 \%$ dan spesifisitas $92 \%$. Mathur et al ${ }^{24}$ tidak menganjurkan menggunakan CRA untuk skrining pemeriksaan biofilm Staphylococcus aureus.

\section{Biofilm pada Rinosinusitis Kronis}

Berbagai penelitian dilakukan untuk mengetahui peran biofilm pada rinosinusitis kronis. Penelitian pertama terhadap peran biofilm dan RSK oleh Perloff dan Palmer yang memeriksa biofilm pada sten yang dipasang pada sinus frontal saat pembedahan pada penderita RSK frontal, menggunakan SEM. Mereka mendapatkan bukti terdapatnya biofilm bakteri pada keenam pasien yang diperiksa. ${ }^{28}$ Perloff dan Palmer juga melakukan penelitian pada mukosa sinus maksilaris kelinci yang diinfeksi dengan Pseudomonas aeruginosa menggunakan SEM memperlihatkan bukti biofilm bakteri pada semua 22 hewan coba. ${ }^{29}$ Penelitian dari laboratorium yang sama juga membuktikan terdapatnya biofilm pada sampel mukosa sinonasal yang diambil dari 16 pasien RSK yang menjalani FESS (Functional Endoscopic Sinus Surgery) yang diperiksa menggunakan SEM. ${ }^{3}$

Tiba et al, ${ }^{21}$ juga menggunakan SEM mendeteksi terdapatnya biofilm bakteri pada 9 (64\%) dari 14 pasien yang diperiksa dengan RSK yang dijadwalkan untuk FESS atau pasien dengan rinisinusitis persisten setelah FESS. Bezerra et al, ${ }^{30}$ mengambil sampel dari bula etmoid dari 9 pasien RSK dengan polip nasi yang tidak respon dengan pengobatan klinis yang menjalani operasi yang diperiksa menggunakan SEM didapatkan 55,56\% (5/9) pasien terdapat biofilm bakteri.

Ferguson dan Stolz, ${ }^{31}$ mendapatkan biofilm bakteri pada 2 dari 4 pasien RSK yang diperiksa menggunakan TEM. Sepertinya ini penelitian biofilm yang pertama menggunakan TEM. Penelitian yang lebih besar oleh Sanclement et al, ${ }^{4}$ mendapatkan 24 (80\%) dari 30 pasien terdapat bukti adanya biofilm yang diperiksa dengan SEM, 6 sampel menggunakan metoda kriofiksasi kemudian diperiksa menggunakan TEM. Keenam sampel menunjukkan struktur biofilm dengan SEM dan berhubungan dengan struktur bakteri yang terdapat pada permukaan mukosa yang tampak dengan TEM. ${ }^{4}$

Prince et $\mathrm{al}^{2}{ }^{2}$ menggunakan metoda modifikasi Calgary Biofilm Detection Assay mendapatkan 45 sampel (28,6\%) dari 157 pasien menunjukkan pembentukan biofilm. Diantara pasien dengan riwayat FESS 30,7\% menunjukkan pertumbuhan biofilm. ${ }^{2}$ Bendouah et al, ${ }^{32,33}$ mendapatkan 22 dari 31 sampel memproduksi biofilm lebih tebal atau sama dengan kontrol positif yang dievaluasi dengan metoda semi-kuantitatif menggunakan kristal violet. Biofilm didapatkan pada $6 / 10$ isolat Pseudomonas aeruginosa, 8/10 isolat Staphylococcus aureus, dan 8/11 Staphylococus koagulase negatif.

Sanderson et al, ${ }^{34}$ mendapatkan 14 dari 18 sampel biopsi mukosa sinus yang diambil dari pasien RSK yang menjalani FESS mengandung biofilm bakteri. Spesimen diperiksa dengan uji FISH dan CSLM untuk Streptococcus pneumonia, Staphylococcus aureus, Haemophilus influenza, dan Pseudomonas aeruginosa. Spesies predominan adalah $H$. influenzae, S. pneumoniae, dan S. aureus. $P$. aeruginosa tidak ditemukan pada spesimen. ${ }^{34}$ Foreman et al, ${ }^{16}$ juga mengunakan FISH dan CSLM mendapatkan 36 dari 50 RSK pasien mengandung biofilm. Staphylococcus aureus merupakan bakteri yang paling umum membentuk biofilm.

Singhal et al, $^{17}$ meneliti 39 pasien yang menjalani FESS untuk mendeteksi spesies bakteri pembentuk biofilm dengan FISH dan CSLM. 30 dari 39 pasien ditemukan mengandung kombinasi spesies bakteri berbeda, 60\% dari 30 biofilm ini merupakan biofilm polimikrobial dan $70 \%$ biofilm S. aureus.

Zernotti et $\mathrm{al}^{35}$ menemukan kemampuan membentuk biofilm pada 9 dari 12 pasien RSK dengan polip nasi. Mikroorganisme yang disolasi adalah Staphylococcus, Streptococcus viridans, Pseudomonas aeruginosa, Enterococcus faecalis dan Streptococcus viridans.

\section{Terapi Potensial untuk Biofilm pada Rinosinusitis Kronis}

Strategi untuk mencegah pembentukan biofilm bervariasi dari pendekatan sistemik sampai lokal. Penggunaan antibiotika oral sering tidak efektif untuk eradikasi bakteri pada biofilm. ${ }^{34}$ Beberapa penelitian berkembang untuk mengatasi biofim ini yang secara umum yaitu menahan pembentukan biofilm dan mengangkat biofilm yang sudah terbentuk. ${ }^{18}$ Penghambatan pembentukan biofilm secara lokal terfokus pada pemusnahan bakteri planktonik sebelum melekat pada permukaan dan menginisiasi pembentukan biofilm. ${ }^{19}$

Untuk menahan pembentukan biofilm berbagai penelitian secara luas dilakukan untuk memanipulasi berbagai stadium perkembangan biofilm dan untuk mengidentifikasi gen yang bertanggung jawab dalam 
pembentukan biofilm. Pendekatan ini terutama berdasarkan manipulasi pada quorum sensing dan juga pada penghambatan molekul sinyal untuk menghambat proses pelekatan. Baru-baru ini para peneliti telah sukses dalam memodulasi quorum sensing menggunakan QS inhibitor. ${ }^{38,39}$

Beberapa bahan yang dapat membantu mengurangi pelekatan sel ke permukaan dan beberapa terapi ditujukan mengurangi atau menghancurkan biofilm yang sudah terbentuk telah banyak diteliti. Beberapa terapi ini termasuk penggunaan surfaktan kimia, seperti detergen, memiliki aktivitas antimikroba dengan merusak dinding sel bakteri. Shampo bayi merupakan larutan komersial yang tersedia mengandung berbagai surfaktan kimia. Surfaktan kimia dapat berperan sebagai mukolitik dengan mengurangi tegangan permukaan air dan berpotensi berperan sebagai agen antimikroba. Chiu et al, ${ }^{40}$ menunjukkan bahwa larutan $1 \%$ shampo bayi dalam salin normal merupakan konsentrasi optimal untuk menghambat pembentukan biofilm oleh Pseudomonas. Alendejani et $\mathrm{al}^{41}$ menunjukkan keefektifan penggunaan madu Hanuka dari Selandia Baru dan madu Sidr dari Yaman, dalam membunuh biofilm bakteri Staphylococcus aureus dan Pseudomonas aeruginosa.

Penelitian in vitro telah menunjukkan bahwa arus listrik dapat meningkatkan aktivitas beberapa agen antimikroba terhadap bakteri tertentu pada biofilm. Hal ini disebut dengan efek bioelektrik. Beberapa hipotesis mekanisme kerja dari efek bioelektrik yaitu menurunkan kapasitas matriks biofilm untuk mengikat agen antimikroba sebelum mencapai sel target dengan merusak matriks tersebut, peningkatan permeabilitas membran, peningkatan hantaran oksigen ke biofilm, pembentukan oksidan, meningkatkan transport melalui elektroosmosis, dan peningkatan temperatur di dalam biofilm. Melalui mekanisme kerja tersebut akan meningkatkan penetrasi antimikroba ke sel target. ${ }^{42}$

Basso et $\mathrm{al}^{43}$ memperlihatkan bahwa setelah pemberian laser dosis rendah dapat menurunkan viabilitas sel dan pertumbuhan biofilm. Laser yang digunakan adalah laser dioda indium gallium arsenide phosphide (InGaAsp) dengan panjang gelombang $780 \pm 3 \mathrm{~mm}$ dan daya 0,4 W. Walaupun tidak terdapat bukti bahwa laser dapat menginduksi kematian sel, tapi dari parameter yang diteliti menunjukkan disorganisasi dan disagregasi dari mikroorganisme dalam biofilm sehingga menghambat pertumbuhan dan metabolismenya. ${ }^{44}$
Penelitian baru menggunakan agen kontrol biologi seperti bakteriofaga sedang berkembang. Bakteriofaga adalah virus yang menginfeksi bakteri. Untuk memasuki sel hospes, bakteriofaga menempel pada reseptor spesifik pada permukaan bakteri. Beberapa peneliti sedang mengembangkan bakteriofaga yang dapat menginfeksi bakteri dalam biofilm. Bakteriofaga pertama yang dikembangkan dapat menginfeksi Pseudomonas sp menggunakan enzim lyase polisakarida yang dapat mendegradasi posisakarida dalam biofilm. ${ }^{45}$ Masih diperlukan penelitian lebih lanjut untuk mendapatkan terapi spesifik yang maksimal terhadap biofilm.

\section{Biofilm dan Resistensi Antibiotik}

Penderita rinosinusitis kronik sering kali hanya menunjukkkan respon positif pemberian antibiotik pada awal terapi, kemudian pada beberapa minggu atau bulan kemudian terjadi relaps dan sulit sekali menemukan organisme patogen jika dilakukan kultur. Biofilm bakteri 10 - 1000 kali lebih resisten terhadap antibiotik dibandingkan infeksi yang disebabkan oleh bakteri planktonik. Hal ini disebabkan oleh proses multifaktorial, antara lain: terhambatnya penetrasi antibiotik oleh maktriks eksopolisakarida dari biofilm, perubahan lingkungan mikro dan berkurangnya angka pertumbuhan, perubahan ekspresi genetik, dan adanya sel yang bersifat persister. ${ }^{18,19}$

Terdapatnya matriks eksopolisakarida pada biofilm telah diketahui berperan pada terbatasnya penetrasi antimikroba ke dalam biofilm. Matriks ini secara fisik mempengaruhi jumlah transportasi antimikroba atau dengan medeaktivasinya sewaktu melewati matriks. $^{20}$

Telah diteliti bahwa biofilm mengandung gradien mikro dari metabolit. Gradien kimia ini berpengaruh terhadap perubahan potensi antibiotik. Tack dan Sabath dikutip oleh Psaltis menunjukkan bahwa kemampuan biofilm untuk oksigenasi sendiri, memodulasi aksi aminoglikosida, sehingga bakteri pada lingkungan anaerob lebih resisten pada antibiotik dibandingkan pada lingkungan aerob. Gradien $\mathrm{pH}$ juga ditunjukkan berpengaruh secara negatif dengan efikasi antibiotik. Pada area dengan nutrisi kurang, penelitian menggunakan probe flouresen dan gen, telah menunjukkan bahwa sel-sel bakteri juga secara signifikan berkurang angka pertumbuhan dan metabolismenya. Hal ini juga berkontribusi terhadap resistensi biofilm terhadap antimikroba. ${ }^{20}$ 
Penelitian microarray dan proteomic DNA telah menunjukkan perbedaan pada ekspresi gen dan profil protein biofilm dan bakteri planktonik. Disimpulkan bahwa peningkatan ekspresi dari gen resistensi spesifik biofilm berkontribusi terhadap resistensi antimikroba. Dari penelitian didapatkan bahwa pada populasi heterogen sel-sel mikroba biofilm, sejumlah kecil dari sub-populasi sel, dianggap sebagai persister. Dipikirkan bahwa sel-sel ini mengadopsi suatu tingkat fenotip untuk pembentukan dan regenerasi biofilm. ${ }^{19,20}$

\section{SIMPULAN}

Rinosinusitis kronis dapat disebabkan oleh interaksi berbagai faktor penyebab yaitu berupa faktor genetik, faktor lingkungan, faktor struktural dan faktor mikroba termasuk di dalamnya adalah biofilm. Banyak penelitian telah menunjukkan

\section{DAFTAR PUSTAKA}

1. Patel ZM, Hwang PH. Nonpolypoid rhinosinusitis: pathogenesis, diagnosis, staging, and treatment. In: Johnson JT, Rosen CA, eds. Bailey's head \& neck surgery otolaryngology. Vol.1. Fifth edition. Philadelphia: Lippincott Williams \& Walkins;2014. P.535-47.

2. Prince AA, Steiger JD, Khalid AN, Dogrhamji L, Reger $C$, Claire $\mathrm{SE}$, et al. Prevalence of biofilm-forming bacteria in chronic rhinosinusitis. Am J Rhinol 2008;22:239-245.

3. Palmer J. Bacterial biofilms in chronic rhinosinusitis. Annals of Otology, Rhinology \& Laryngology 2006;115(9)Suppl 196:35-9.

4. Sanclement JA, Webster P, Thomas J, Ramadan HH. Bacterial biofilms in surgical specimens of patients with chronic rhinosinusitis. Laryngoscope 2005;115:578-82.

5. Galli J, Ardito F, Calo L, Mancinelli L, Imperiali M, Parrilla C, et al. Recurrent upper airway infections and bacterial biofilms. The Journal of Laryngology \& Otology 2007;121:341-4.

6. Tamashiro E, Antunes MB, Palmer JN, Cohen NA, Anselmo-Lima WT. Implication of bacterial biofilms in chronic rhinosinusitis. BJID 2009;13(3):232-5.

7. Stodley LH, Hu FZ, Gieseke A, Nistico L, Nguyen D, Hayes J, et al. Direct detection of bacterial biofilms on the middle ear mucosa of children with chronic otitis media. JAMA 2006;296:202-11.

8. Galli J, Calo L, Ardito F, Imperiali M, Basotti E, Fadda $G$, et al. Biofilm formation by Haemophilus influenza isolated from adenotonsil tissue samples and its role in recurrent adenotonsillitis. Acta otorhinolaryngologica italic 2007;27:134-8.

9. Peric A, Gacesa D. Etiology and pathogenesis of chronic rhinosinusitis. Vojnosanit Pregl. 2008;65(9):699-702.

10. Hamilos DL. Chronic rhinosinusitis: Epidemiology and medical management. J Allergy Clin Immunol. 2011;128:693-7. terdapatnya biofilm bakteri pada pasien dengan RSK. Berbagai pemeriksaan untuk mendeteksi biofilm yaitu Scanning Electron Microscopy (SEM), Transmission Electron Microscopy (TEM), Confocal Scanning Laser Microscopy (CSLM), dan in vitro assay: modifikasi Calgary Biofilm Device Assay, tube method, Congo Red Agar method. Beberapa terapi potensial untuk mengatasi biofilm pada RSK sedang berkembang seperti quorum sensing inhibitor, surfaktan kimia, madu, bioelektrik, laser, dan bakteriofaga. Keberadaan biofilm ini diduga penyebab kegagalan terapi antibiotika.

\section{KONFLIK KEPENTINGAN}

Tidak ada

11. Reh DD, Higgins TS, Smith TL. Impact of tobacco smoke on chronic rhinosinusitis - a review of the literature. Int Forum Allergy Rhinol. 2012;2(5):362-9.

12. Cohen NA, Zhang S, Sharp DB, Tamashiro E, Chen B, Sorscher EJ, et al. Cigarette smoke condensate inhibits transepithelial chloride transport and ciliary beat frequency. Laryngoscope 2009;119(11):2269-74.

13. De la Hoz RE, Shohet MR, Cohen JM. Occupational rhinosinusitis and upper airway disease: the world trade center experience. Curr Allergy Asthma Rep. 2010;10(2):77-83.

14. Leid JG, Cope EK, Parmenter S, Shirtliff ME, Dowd S, Wolcott $\mathrm{R}$, et al. The importance of biofilms in chronic rhinosinusitis. Dalam: Bjarnsholt $\mathrm{T}$, et al, eds. Biofilm infection. LLC: Springer science + business media, 2011. P.139-60.

15. Boase S, Foreman A, Cleland E, Tan L, Melton-Kreft R, Pant $H$, et al. The microbiome of chronic rhinosinusitis: culture, molecular diagnostic and biofilm detection. BMC Infectious Disease 2013;13:210-7.

16. Foreman A, Psaltis AJ, Tan LW, Wormald PJ. Characterization of bacterial and fungal biofilms in chronic rhinosinusitis. Am J Rhinol Allergy. 2009;23:556-61.

17. Singhal D, Foreman A, Bardy JJ, Wormald PJ. Staphylococcus aureus biofilms: nemesis of endoscopic sinus surgery. Laryngoscope 2011;121:1578-83.

18. Antony A. Study of biofilm forming capacity of pathogen involved in chronic rhinosinusitis. Disertasi. Auckland: Auckland university of technology;2011.

19. Fux CA, Stoodley P, Stoodley LH, Costerton JW. Bacterial biofilms: a diagnostic and therapeutic challenge. Expert Rev. Anti-infect Ther. 2003;1(4):667-83.

20. Psaltis AJ. The role of bacterial biofilms in chronic rhinosinusitis. Disertasi. Department of surgery, Faculty of Health Sciences, The Queen Elizabeth 
Hospital/University of Adelaide, South Australia, 2008.

21. Tiba M, Youssef T, Al-Ajlan A. Does bacterial biofilms have a role in the development of human chronic rhinosinusitis? EJENTAS 2009;10:1-4.

22. Ceri $H$, Olson ME, Stremick $C$, Read R, Morck D, Buret A. The Calgary biofilm device: new technology for rapid determination of antibiotic susceptibilities of bacterial biofilms. J. Clin.Microbiol. 1999;37(6):17716.

23. Christensen GD, Simpson A, Bisno AL, Beachey EH. Adherence of slime-producing strains of Staphylococcus epidermidis to smooth surfaces. Infection and immunity 1982;37:318-326.

24. Mathur T, Singhal S, Khan S, Upadhyay DJ, Fatma T, Rattan A. Detection of biofilm formation among the clinical isolates of staphylococci: an evaluation of three different screening methods. Indian J Med Microbiol. 2006;24:25-9.

25. Oliveira A, Cunha MLRS. Comparison of methods for the detection of biofilm production in coagulasenegative staphylococci. BMC 2010;3:260.

26. Hassan A, Usman J, Kaleem F, Omair M, Khalid A, Iqbal M. Evaluation of different detection methods of biofilm formation in the clinical isolates. Braz J Infect Dis 2011;15(4):305-11.

27. Freeman DJ, Falkiner FR, Keane CT. New methode for detecting slime production by coagulase negative staphylococci. J Clin Pathol 1989;42:872-4.

28. Perloff JR, Palmer JN. Evidence of bacterial biofilms on frontal recess stents in patients with chronic rhinosinusitis. American Journal of Rhinology 2004;18(4):377-80.

29. Perloff JR, Palmer JN. Evidence of bacterial biofilms in a rabbit model of sinusitis. American Journal of Rhinology 2005;19(1):1-6.

30. Bezerra TFP, MeloPadua FC, Ogawa Al, Gebrim EM, Sadiva PHN, Voegels RL. Biofilm in chronic rhinosinusitis with nasal polyps: pilot study. Braz J. Otorhinolaryngol. 2009;75(6):788-93.

31. Ferguson BJ, Stolz DB. Demonstration of biofilm in human bacterial chronic rhinosinusitis. American Journal of Rhinology 2005;19:452-7.

32. Bendouah Z, Barbeau J, Hamad WA, Desrosiers M. Use of in vitro assay for determination of biofilmforming capacity of bacteria in chronic rhinosinusitis. Am J Rhinol. 2006;20:434-8.

33. Bendouah Z, Barbeau J, Hamad WA, Desrosiers. Biofilm formation by Staphylococcus aureus and Pseudomonas aeruginosa is associated with an unfavorable evolution after surgery for chronic sinusitis and nasal polyposis. Otolaryngol Head Neck Surg. 2006;134:991-6.

34. Sanderson AR, Leid JG, Hunsaker D. Bacterial biofilms on the sinus mucosa of human subjects with chronic rhinosinusitis. Laryngoscope 2006;116:1121-6.

35. Zernotti ME, Villegas NA, Revol MR, Cagnani CE, Miranda JE, Paredes ME, et al. Evidence of bacterial biofilms in nasal polyposis. J Investig Allergol Clin Immunol. 2010;20(5):380-5.

36. Suh JD, Chiu AG. Medical management of chronic sinusitis. In: Johnson JT, Rosen CA, eds. Bailey's head $\&$ neck surgery otolaryngology. Vol.1. Fifth edition. Philadelphia: Lippincott Williams \& Walkins;2014. P.586-594.
37. Fokkens W, Lund V, Mullol J, et al. European position paper on rhinosinusitis and nasal polyps. Rhinology, 2007; 45(suppl 20): 1-139.

38. Rasmussen TB, Bjarnsholt $T$, Skindersoe ME, Hentzer $M$, Kristofferson $P$, Kote $M$, et al. Screening for quorum-sensing inhibitors ( $Q S I)$ by use of a novel genetic system, the QSI selector. Journal of bacteriology 2005;187:1799-1814.

39. Rasmussen TB, Givskov M. Quorum sensing inhibitors: a bargain of effects. Microbiology 2006;152:895-904.

40. Chiu AG, Palmer JN, Woodworth BA, Doghramji L, Cohen MB, Prince $A$, et al. Baby shampoo nasal irrigations for the symptomatic post-functional endoscopic sinus surgery patient. Am J Rhinol. 2008;22:34-7.

41. Alandejani T, Marsan J, Ferris W, Slinger R, Chan F. Effectiveness of honey on Staphylococcus aureus and Pseudomonas aeruginosa biofilms. OtolaryngologyHead and Neck Surgery 2009;141:114-8.

42. Del Pozo JL, Rouse MS, Patel R. Bioelectric effect and bacterial biofilm. A systematic review. Int J Artif Organs. 2008;31(9):786-95.

43. Basso FG, Oliveira CF, Fontana A, Kurachi C, Bagnato VS, Spolidorio DMP, et al. In vitro effects of low level laser therapy on typical oral microbial biofilms. Braz Dent J. 2011;22(6):502-10.

44. Cortes ME, Bonilla JC, Sinisterra RD. Biofilm formation, control and novel strategies for eradication. In: Vilas AM, ed. Science against microbial pathogens communicating current research and technological advances. Brazil: Formatex;2011. p.896-905.

45. Harper DR, Parracho HMRT, Walker J, Sharp R, Hughes $G$, Werthen $M$, et al. Bacteriophages and biofilms. Antibiotics 2014;3:270-84. 